\title{
Experience of Using Information Systems in Public Health Practice: Findings from a Qualitative Study
}

\author{
Joshua R Vest, PhD, MPH', L. Michele Issel, PhD, RN², Sean Lee, MPH² \\ 1. Center for Healthcare Informatics \& Policy, Division of Quality and Medical Informatics, Department \\ of Public Health, Weill Cornell Medical College \\ 2. Community Health Sciences Division, School of Public Health, University of Illinois at Chicago
}

\begin{abstract}
Objective: Data collection and management by local health departments (LHDs) is a complex endeavor, complicated by system level and organizational factors. The purpose of this study was to describe the processes and use of information systems (IS) utilized for data collection, management, and sharing by LHD employees.

Methods: We interviewed a purposive sample of 12 staff working in the key public health practice areas of communicable disease control, immunizations, and vital records from three LHDs in different states. Our interview questions addressed job descriptions, daily activities, and the use and perceptions of both data and IS in support of their work. A content analytic approach was used to derive themes and categories common across programmatic areas.

Results: Local public health involves the use of mix of state-supplied and locally implemented IS supported by paper records. Additionally, each LHD in this study used at least one shadow system to maintain a duplicate set of information. Experiences with IS functionality and the extent to which it supported work varied by programmatic area, but inefficiencies, challenges in generating reports, limited data accessibility, and workarounds were commonly reported.

Conclusions: Current approaches to data management and sharing do not always support efficient public health practice or allow data to be used for organizational and community decision making. Many of the challenges to effective and efficient public health work were not solely technological. These findings suggest the need for interorganizational collaboration, increasing organizational capacity, workflow redesign, and end user training.

Key words: information systems, immunization, Public Health Informatics, vital statistics, public health administration

Correspondence: jov2025@med.cornell.edu

DOI: 10.5210/ojphi.v5i3.4847

Copyright @2014 the author(s)

This is an Open Access article. Authors own copyright of their articles appearing in the Online Journal of Public Health Informatics. Readers may copy articles without permission of the copyright owner(s), as long as the author and OJPHI are acknowledged in the copy and the copy is used for educational, not-for-profit purposes.
\end{abstract}




\section{Introduction}

Public health services delivery depends on data and information for enumeration and reporting as part of disease surveillance [1], preventive and medical service delivery [2], local decision making, strategic planning, and quality improvement [3-5]. Such activities make reporting and managing data substantial portions of local public health practitioners daily job activities [6]. However, local public health practitioners work within systems and organizations that can present challenges to the effective collection, management, and sharing of data [7].

Data collection and management in public health practice is a complex endeavor. These efforts require exchanging data with multiple organizations due to overlapping jurisdictional boundaries, shared responsibilities, and mobile populations [7-10]. Generally, increasing the number of data sources increases challenges around maintaining information quality [11]. Additionally, each LHD is often home to a variety of different data management approaches [12], which can include multiple or programmatic-specific information systems (IS) that are not capable of electronically sharing information in a standards-based structured fashion, or reliance on a combination of paper and IS [13-17]. This too creates complications as increasing the number of IS which an individual must use increases the complexity of work and negatively affects productivity [12]. Also, that insufficient or non-interoperable IS can have negative effects on the ability of public health organizations to effectively plan, respond in a timely manner to events, or operate efficiently [18-20]. In fact, evidence indicates the inability to electronically transmit or receive data is the norm for many public health activities [21].

The interaction of individual need for information and presence of a complex arrangement lead us to enrich our understanding of LHD data use, management, and IS characteristics through insights from the lived IS experiences of public health practitioners. We specifically framed our investigation in the context of data gathered and shared between LHDs and state health agencies (SHA) in order to focus on the use of information that is a product of the entire public health system. We selected the activities of immunization delivery, communicable disease control, and vital records as they are performed by a majority of LHDs [17], require data gathering and sharing by multiple public health entities, and these program areas are subject to structural barriers to information sharing [21]. We specifically sought to characterize the perceived IS needs and barriers, as well as IS uses and work-around solutions to accomplish the program goals.

\section{Methods}

The qualitative study design involved a purposive sample of LHD employees and open-ended interviews. A content analytic approach was used to derive themes and categories common across programmatic areas.

\section{Sample}

In mid-2012, one member of the research team (A1) interviewed 12 staff working in the areas of communicable disease control $(n=4)$, immunizations $(n=4)$, and vital records $(n=4)$ from three 
LHDs. The three sites were each in different states and included an urban, a rural, and a suburban LHD (Table 1). The sites were selected through our existing organizational contacts with the only requirement that they conducted all three public health activities. Informants had the various titles of epidemiologist, program coordinator, nurse, manager, or registrar. We purposefully interviewed those who were responsible for gathering and data sharing.

\section{Data Collection}

Data were collected on-site in order to observe IS and data collection forms. The semi-structured, open-ended interview guide addressed job descriptions, activities, and the use and perceptions of data and IS in support of work. Research into the high prevalence of data sharing gaps [21] and existing instruments measuring IS quality [22,23] informed questionaire development. Interviews lasted approximately 45 minutes. Consent to interview personnel was first obtained from each LHD's chief administrative officer and then from each interviewee.

\section{Data Analysis}

Analysis followed a general inductive approach [24]. Independently, JV and MI read the transcripts and employed open coding to identify tentative categories. Both team members have worked in local public health. The independently derived codes were reduced by consolidating overlapping categories and identifying higher-level themes. Discussion resolved differences and resulted in a category labels and descriptions. To validate the thematic codes, SL independently conducted closed-coding of all transcripts. A sample set of documents from each program area indicated $>90 \%$ agreement between three sets of coders. Lastly, we also conducted member checking; one informant reviewed their transcript and concurred with the assigned coding.

\section{Results}

LHDs used a mix of multiple IS supported by traditional paper forms, telephone calls, and faxes to collect and share all the data necessary to complete their daily work. The IS included both state-provided and locally implemented systems as well as business process oriented IS like practice management systems (Table 1). As indicated, the IS in use were very specific. Each programmatic area used its own IS and for the communicable disease programs the IS were frequently disease-specific.

Table 1. Characteristics and information systems in use at interviewed local health departments by programmatic area.

\begin{tabular}{|l|l|l|l|l|}
\hline & & Data Management or Information Systems (IS) Used \\
\hline $\begin{array}{l}\text { Health } \\
\text { department }\end{array}$ & $\begin{array}{l}\text { Number } \\
\text { Of staff } \\
\text { interviewed }\end{array}$ & $\begin{array}{l}\text { Communicable } \\
\text { Disease }\end{array}$ & Immunization & Vital records \\
\hline Rural & 3 & $\begin{array}{l}\text { Electronic Labs } \\
\text { Practice } \\
\text { management } \\
\text { Paper records }\end{array}$ & $\begin{array}{l}\text { IIS }^{3} \\
\text { Practice management }\end{array}$ & $\begin{array}{l}\text { VRIS } \\
\text { Paper records } \\
\text { Spreadsheets }\end{array}$ \\
\hline
\end{tabular}




\begin{tabular}{|l|l|l|l|l|}
\hline Suburban & 4 & $\begin{array}{l}\text { Surveillance IS } \\
\text { STD IS } \\
\text { Local database } \\
\text { Spreadsheets } \\
\text { Paper records }\end{array}$ & $\begin{array}{l}\text { IIS }^{3} \\
\text { MCH IS }^{6} \\
\text { Practice management } \\
\text { Paper records }\end{array}$ & $\begin{array}{l}\text { VRIS } \\
\text { Paper records } \\
\text { Spreadsheets }\end{array}$ \\
\hline Large urban & 5 & $\begin{array}{l}\text { Surveillance IS } \\
\text { STD IS } \\
\text { HIV IS } \\
\text { Spreadsheets } \\
\text { Paper records }\end{array}$ & $\begin{array}{l}\text { IIS }^{3} \\
\text { Statewide client } \\
\text { management IS } \\
\text { Inventory management IS } \\
\text { Vaccine for children } \\
\text { provider IS } \\
\text { Practice management }\end{array}$ & $\begin{array}{l}\text { VRIS } \\
\text { Paper records } \\
\text { Local database }\end{array}$ \\
\hline
\end{tabular}

${ }^{1}$ Quality, functions, interoperability, or perceptions of IS are not reported here.

${ }^{2}$ Practice management includes billing \& scheduling functions

${ }^{3}$ Immunization Information System (statewide system)

${ }^{4}$ Vital Records Information System (statewide system)

${ }^{5}$ Statewide communicable disease (and HIV/STD) surveillance systems

${ }^{6}$ Maternal Child Health Information System (statewide system)

We identified 46 categories within 11 themes (see Appendix). We present the four most salient to the majority of interviewees in detail with illustrative quotes in Table 2.

Table 2. Themes and corresponding categories regarding public health information systems (IS) and technology.

\begin{tabular}{|l|l|l|}
\hline Selected theme & $\begin{array}{l}\text { Selected } \\
\text { category }\end{array}$ & Specific areas \& example quote \\
\hline $\begin{array}{l}\text { Factors } \\
\text { infocting } \\
\text { system quality }\end{array}$ & $\begin{array}{l}\text { Information } \\
\text { system quality - } \\
\text { reporting / } \\
\text { output capability } \\
\text { that affect specific quality characteristics or overall } \\
\text { quality of the data within the IS }\end{array}$ & $\begin{array}{l}\text { "“..it's not a report writing system in the sense that I } \\
\text { would think it is where it generates aggregate } \\
\text { output... when we run a report we're basically creating } \\
\text { another data file." - Epidemiologist, urban LHD } \\
\text { "We do have the opportunity to run some reports. But, to } \\
\text { be honest with you, it's so difficult to run a report that no } \\
\text { one does it." - Communicable Disease, suburban LHD }\end{array}$ \\
\hline & $\begin{array}{l}\text { "Our health department providers that use [the IIS], } \\
\text { they're like, "Really? We have to input everything into } \\
\text { interoperability } \\
\text { [the IIS] and then at the end of the month we have to do } \\
\text { it again into [Vaccine management system]?" And it } \\
\text { would be a lot easier, yeah, if they talked to each } \\
\text { other..." - Immunization coordinator, urban LHD }\end{array}$ \\
\hline $\begin{array}{l}\text { The system level context, organizational level factors, } \\
\text { or situations that affect the need or ability of staff to }\end{array}$ \\
\hline Bata
\end{tabular}




\begin{tabular}{|c|c|c|}
\hline \multirow[t]{4}{*}{$\begin{array}{l}\text { acquisition } \\
\text { from others }\end{array}$} & & get information from other organizations or sources \\
\hline & $\begin{array}{l}\text { Jurisdictionally } \\
\text { defined work }\end{array}$ & $\begin{array}{l}\text { "The access we have now for neighboring counties is just } \\
\text { that we can put a name in and we can see it's in there, but } \\
\text { we can't necessarily see the disease or see what's going } \\
\text { on there." - Nurse, urban LHD } \\
\text { "You just don't have the ability to see everything that's } \\
\text { going on, because some things are blocked." - } \\
\text { Communicable Disease, suburban LHD }\end{array}$ \\
\hline & $\begin{array}{l}\text { Mobile } \\
\text { populations }\end{array}$ & $\begin{array}{l}\text { "Confidentiality. They don't wanna be known wherever } \\
\text { they're going. So if they feel like they can't have the } \\
\text { confidentiality there in [city in neighboring state], then } \\
\text { they'll come here and be tested." - Public health nurse, } \\
\text { rural LHD }\end{array}$ \\
\hline & Data ownership & $\begin{array}{l}\text { "We need our data back, and we need it back } \\
\text { immediately... [The SHA is] looking at it simply as } \\
\text { data... What that means to us is much more important." - } \\
\text { Registrar, urban LHD }\end{array}$ \\
\hline \multirow{2}{*}{$\begin{array}{l}\text { Barriers to } \\
\text { effective data } \\
\text { sharing (to } \\
\text { others) }\end{array}$} & & $\begin{array}{l}\text { Experienced and reported difficulties, challenges or } \\
\text { factors/situations that need to be overcome/addressed } \\
\text { in order to provide data to others }\end{array}$ \\
\hline & Reporting back & $\begin{array}{l}\text { "So it seems like our staff in the unit have to pull } \\
\text { information from [IS], put it on a separate piece of paper, } \\
\text { and then send it to the state. So I'm not sure why we } \\
\text { have to add that extra step when I feel like, in an ideal } \\
\text { world, we would be able to use [the IS] to report on the } \\
\text { information that they need since there already is a way } \\
\text { for us to collect it.' - Epidemiologist, urban LHD }\end{array}$ \\
\hline \multirow[t]{4}{*}{$\begin{array}{l}\text { Consequences } \\
\text { of Data } \\
\text { Sharing } \\
\text { Barriers and } \\
\text { ISQ Problems }\end{array}$} & & $\begin{array}{l}\text { All consequences or outcomes associated with the } \\
\text { inability to efficiently secure desired information } \\
\text { from other sources and of having poor data quality }\end{array}$ \\
\hline & $\begin{array}{l}\text { Duplication of } \\
\text { work/re-work / } \\
\text { inefficient work }\end{array}$ & $\begin{array}{l}\text { "If you got a parent that's not a good steward of records, } \\
\text { they could possibly have that same child immunized } \\
\text { about } 3 \text { or } 4 \text { times by the certain age and they don't } \\
\text { necessarily need all those vaccines." - Immunization } \\
\text { staff, rural LHD }\end{array}$ \\
\hline & Workarounds & $\begin{array}{l}\text { "We were having to write everything in the comment } \\
\text { field for zoonosis." - Public health nurse, urban LHD }\end{array}$ \\
\hline & Shadow IS & $\begin{array}{l}\text { "We're duplicating our reporting. We do one for in house } \\
\text { to help us keep track, and then we use the state system." } \\
\text { - Communicable disease, suburban LHD }\end{array}$ \\
\hline
\end{tabular}




\section{Factors Affecting IS Quality}

This theme encompassed factors, circumstances, and conditions that effected specific quality characteristics or overall quality of the data within the IS. Also included in this theme are assessments or views on the quality of the IS itself in terms of the user experience, available data, and reporting features.

Reporting functionality is important for public health IS since being able to generate aggregated statistics or line listings from data is critical to case investigation and community assessments. Interviewees, however, frequently mentioned difficulty using the reporting capabilities of their IS: the system did not produce reports in a desired format; reports were too difficult to obtain; or the capability to run reports wasn't present at all. Reporting was generally absent for vital records. The registrar in the rural LHD did not run reports, but neither did the SHA share reports with her. The complete absence of reporting functionality at the suburban LHD forced vital records staff to do manual counts off screen displays. The urban LHD could not run reports from their SHA-supplied IS either.

Instances of interoperable IS supported work existed, with immunization programs more integrated than other programmatic activities. Interoperable IS use standards to ensure the meaning and usability of data are preserved when exchanged. The rural LHD used a public health-specific practice management system that could export data into the state's immunization IS (IIS) eliminating the need for double data entry. However, the urban and suburban's IIS did not have true-bidirectional data sharing with other applications. Interoperability was limited to data only being able to share in one direction, restrictions on having records in one system first, or only being able to share data for children and not adults. As a result, those IIS were not truly comprehensive sources of information on immunizations or data had to still be actively managed and re-entered by staff.

Due to the high degree of centralized control over registration, the vital records IS were near to being true enterprise-wide systems, e.g. a single IS served the entire state. As a result there were no other "official" public health systems with which the IS had to be interoperable.

\section{Barriers to Data Acquisition \& Sharing}

More than any other theme, the categories of data in this theme focused on the role of public health system and organizational level factors in data management. Issues fundamental to public health, like jurisdictionally defined work, measurement of populations, and data ownership, each affected how practitioners obtained or shared data. This theme was evident across all programmatic areas and LHDs.

Often practitioners knew relevant data existed elsewhere, but could not access it. For one, interviewees confirmed mobile populations fragmented client data. For example, a nurse from the rural LHD explained that a sizable percentage of her clients were actually from a large city in a neighboring state. Additionally, jurisdictional boundaries translated into restrictions on data access. This was true even for programs with shared IS. If a nurse at the urban LHD reported a case, but investigation determined the individual lived in another county, eventually her ability to view much of the detail on the case would be limited. The suburban LHD reported the same 
issue. For vital records, viewing and editing were also curtailed for out of jurisdiction individuals. The exception among the group was immunizations: the capability to get or view out-of-jurisdiction information was less of an issue due to shared IIS.

Issues around which agency controls data, regardless of how collected, were most pronounced at the urban LHD. For communicable diseases and vital records, staff did not have direct control over, or even direct access to the data they collected on their community. Instead they relied on extracted datasets from the SHA. Despite the lack of control, the LHD believed they owned the data.

Few practitioners reported barriers to getting data to the SHA, which was not surprising since the SHA supplied most of the main IS or the SHA was receiving paper forms. Instead, practitioners mentioned idiosyncratic work processes, the complexity of dealing with multiple departments, and narrow reasons for sharing data. For example, reportable condition staff at two LHDs mentioned having to run reports for the state when the information was already available in a shared IS. Lastly, for most locals, data sharing with the SHA was part of business processes: immunization programs for monitoring inventory and compliance; vital records for registration and issuance; and communicable disease programs were "required". While local practitioners valued data, they generally did not recognize value in sharing data with the SHA.

\section{Consequences of Data Sharing Barriers and IS Quality Problems}

Many examples of inefficient and wasted effort could be expected from challenges with technology: double data entry, submitting extra paper copies of forms along with electronic data, multiple phone calls, and duplicated information requests. IS could even complicate the relationships with local providers if they too were forced to do double data entry.

Likewise, workarounds existed to both inputting and retrieving data. For example, communicable disease staff used comment fields to record information in the SHA provided IS. This practice was disease specific as some conditions had IS fields that corresponded to all the information captured on paper field records, but others did not. Getting data back out of systems was often difficult, because not all fields could be queried or local staff did not have access rights. To get around this challenge, communicable disease staff would call SHA employees with the sufficient access to request custom reports or for specific inquires.

Each LHD in this study used at least one shadow system, a parallel IS that only existed to provide easy access to data already stored somewhere else [25]. These additional IS ranged from spreadsheets listing cases to local relational databases designed to manage all aspects of public health reporting and analysis. The origins of the systems were primarily linked to inaccessible data, the need to retain data that could not be entered into state IS, or differences between local's and the state's preferences for data management and recording. Public health practitioners easily justified the use of shadow systems: their "home-grown" systems provided timelier, more complete, more accessible, more accurate, and more useful data than the "official" state repositories. 


\section{Use of Information}

Across all programmatic areas, public health agencies collect data for action. Interviewees recognized the value of data to both their agencies and their constituents. Additionally, they identified applications for the data whether it was for managerial decision making, information sharing with the SHA, or for the potential to improve public health.

Unfortunately, interviews revealed IS quality, data sharing barriers, and organizational capabilities individually or combined made the turning of data into information difficult. Some of the most striking limitations on the use of information were around management decisions and strategic planning (Table 3). Lack of reporting capabilities or insufficiently detailed reports limited the ability of the LHDs to use that information for broader planning purpose. Also the lack of integration between the systems did not allow staff to "pull that information out and utilize it effectively". Sometimes it was employee's skillsets or competing responsibilities, but other times practitioners did not see the value in aggregated information.

\section{Discussion}

The process of acquiring, managing, and sharing public health data at the local level is complex. Numerous IS of varying quality and capability both support and complicate the process. Our interviews with public health practitioners revealed a need to improve data sharing efforts and activities in order to promote efficient public health practice, support decision making, and ensure confidentiality and security.

LHDs are obligated to share data on their communities with their SHA [26] and the interviewed LHDs were meeting that obligation. However, difficulties and inefficiencies permeated the entire process. These challenges are not surprising and almost natural outcomes of the complicated and multi-faceted mechanisms and processes by which LHDs collect and manage data. For example, each program needed multiple IS in order to provide services or public health activities. The use of multiple, different IS complicates work through multiple passwords, log-ins, and switching between systems [12]. If interoperability is absent in a multi-system environment, as was often the case in our observations, then double data entry and other inefficiencies result. Lastly, the continued reliance on paper as an important part of data management also contributes to inefficient work. Hybrid paper-IS data management approaches are slower and less productive than IS alone [27,28].

Table 3. Quotes explaining the challenges to turning data into information for public health practice according to local health departments

\begin{tabular}{|l|l|}
\hline Staff Position, LHD & Quote \\
\hline $\begin{array}{l}\text { Communicable disease } \\
\text { supervisor, Suburban } \\
\text { LHD }\end{array}$ & $\begin{array}{l}\text { "I feel like there's a lot of data that comes in, but there's not a lot } \\
\text { of data that goes back out into the community... Why are we } \\
\text { collecting all this data if we're not informing people of what we're } \\
\text { finding?" }\end{array}$ \\
\hline $\begin{array}{l}\text { Vital records staff, } \\
\text { Suburban LHD }\end{array}$ & $\begin{array}{l}\text { "The [LHD director] wants the information for statistics and } \\
\text { sharing with city planning to see where risk areas may be...The }\end{array}$ \\
\hline
\end{tabular}




\begin{tabular}{|l|l|}
\hline & $\begin{array}{l}\text { state does have canned reports that we can request, but he wants } \\
\text { more specific and that we cannot get it from the state or we can't } \\
\text { generate it ourselves without individually going through each birth } \\
\text { certificate and pulling out the information we need." }\end{array}$ \\
\hline $\begin{array}{l}\text { Epidemiologist, Urban } \\
\text { LHD }\end{array}$ & $\begin{array}{l}\text { "For the most part, the state reports, they don't always have the } \\
\text { data that we need at the local level. And since we can't run reports } \\
\text { at the local level, we do have to go back to the state to request the } \\
\text { information." }\end{array}$ \\
\hline $\begin{array}{l}\text { Epidemiologist, Urban } \\
\text { "...People at the state have found that sometimes their own data } \\
\text { release policy is too restrictive and there's definitely people who } \\
\text { work there that do realize that there is some value in releasing } \\
\text { some aggregate data so any of the stakeholders who are interested } \\
\text { in it could learn something from it." }\end{array}$ \\
\hline $\begin{array}{l}\text { Communicable disease } \\
\text { "I don't know how to run reports well enough for STD yet to be } \\
\text { able to feel comfortable pulling the data and using it for strategic } \\
\text { planning. I would rely on our old manual paper because I know } \\
\text { that is accurate." }\end{array}$ \\
\hline $\begin{array}{l}\text { Nurse supervisor, } \\
\text { Suburban LHD }\end{array}$ & $\begin{array}{l}\text { 'Okay so busy dealing with the day-to-day activities that it's like, } \\
\text { truly right now I'm just kinda like overwhelmed ..." }\end{array}$ \\
\hline $\begin{array}{l}\text { Communicable disease } \\
\text { staff, Rural LHD }\end{array}$ & $\begin{array}{l}\text { I've heard them talk about making reports...but I really don't have } \\
\text { the need for it right now." } \\
\text { Immunization program } \\
\text { "The biggest challenge we have is the overall integration of the } \\
\text { data systems. So it's not just immunizations, it's STD and } \\
\text { communicable disease and everything that they're doing, there's } \\
\text { health information in there, but I don't think there's anybody that } \\
\text { really knows how to pull that information out and utilize it } \\
\text { effectively. We have such a patchwork that there's no way, without } \\
\text { an incredible amount labor and resource, to sort of pull those } \\
\text { things together." }\end{array}$ \\
\hline
\end{tabular}

Several IS characteristics thwarted public health professionals efforts to turn data into information for planning and decisions making purposes. Lack of interoperability and multiple IS did not support obtaining a complete picture of the health of a community. Also important was the absence or ineffective reporting features in several IS. The ability to access information in a meaningful and easy manner is a marker of IS quality [22]. More importantly, without accessible information LHDs were limited in their ability to use evidence-based decisionmaking, engage in strategic planning, or undertake quality improvement efforts [3-5,29]. When LHDs do not possess sufficient internal data capabilities, they rely on the SHA [30]. In these instances, LHDs need to work with cooperatively with their SHA counterparts to identify reports that meet their local needs.

While IS quality complicated work, our finding suggest that attempts to improve data management in public health practice need to adopt a socio-technical perspective. Sociotechnical theory emphasizes the interplay between IS, individuals, and their broader contextual work environments to improve IS effectiveness [31,32]. As an example of this dynamic, we 
documented the influence of state policies on data management and usage issues. Communicable disease and vital record staff routinely employed IS that contained information to which they felt they needed access in order to effectively do their jobs, or it was information they themselves had created. Yet, that information was unavailable solely due to policy and not due to technology. Likewise, practitioners did not always possess the skills to effectively use all of the IS capabilities. Under these types of contextual constraints or skills, problems will not be addressed by simply upgrading or buying a new IS. Given financial limitations facing many agencies nationwide, upgrades or new technologies may not be feasible anyway. Instead solutions to these problems will come from inter-organizational collaboration, increasing organizational capacity, workflow redesign, and end user training.

The prevalence of shadow systems represents an area of concern. Shadow IS are a consequence of a failure, or perceived failure, of the enterprise IS to meet users' needs [25,33]. These needs can be access to information or desired analytics and reporting capabilities [34]. In this way, shadow systems are an extreme case of a workaround; practitioners want to do their job enough that they are willing to duplicate entire systems. Shadow systems, even rudimentary spreadsheets, come at a cost: they must be created, they often require double data entry, and they must be supported and maintained. As another potential cost, they are a security and a privacy threat [35]. Older systems do not have the same security protections as newer IS and accidental disclosure of confidential public health information has happened in the past, because sensitive information was recorded on spreadsheets [36].

Finally, IS presence, quality, functionality, and governance differed by programmatic area. As a result, within each LHD, IS capabilities and experiences varied widely and staff even functioned under different access policies for patients or cases outside their jurisdiction. The categorical and disease-specific nature of public health funding [37,38] may contribute to these different experiences. For example, immunization staff had greater capabilities and policies facilitating information access, probably due to the decade long investment and national priority around childhood immunizations and IIS [39]. Current trends may address these differences in IS; specifically, public health accreditation places an emphasis on understanding data sources, technology; and community planning requires data [40]. A coupling of improved organizational awareness with flexibility around funding and investments would help address the wide variation in IS [38].

\section{Study Limitations}

We interviewed a diverse set of LHDs and explored three major program areas, but the findings may not generalize to other departments or activities. Our small sample may not be nationally representative of the experiences of practitioners, where IS and data quality issues may be common [6,7,12]. We also acknowledge that or perspective on data sharing is limited; we have no data from the SHA perspective. This would be an important avenue for future data collection as SHAs tend to have more advanced IS capabilities than LHDs, but have more partners with which to share data. Additionally, IS is a critical mechanism to link the efforts of public health and the healthcare system [41], but our interviews did not fully investigate that area. Given the current national emphasis on health information exchanges and electronic medical records [42], we 
acknowledge that the results reflect a current reality that might be rapidly changing in many LHDs.

\section{Conclusions}

Local public health involves the use of multiple IS supported by paper records. Current approaches to data management and sharing do not always support efficient public health practice nor allow data to be used for organizational and community decision making. Some of these challenges can be addressed through SHAs cooperatively working with LHDs in the state to define standard work processes and to establish IS governance that supports local practice.

\section{Acknowledgements}

The project was approved by the Institutional Review Boards of Georgia Southern University and Weill Cornell Medical College. We thank Julie Beth Heiniger for her assistance with data management. The contributions of L. Michele Issel, Sean Lee and Julie Beth Heiniger were supported in part by HRSA Bureau of Health Profession, Division of Nursing, Grant \# D11HP14605.

\section{Conflict of Interest}

The authors have no conflicts of interest to declare, financial or otherwise.

\section{References}

1. Lee LM, Thacker SB. 2011. The cornerstone of public health practice: public health surveillance, 1961--2011. MMWR Surveill Summ. 60(Suppl 4), 15-21. PubMed

2. Schauer SL, et al. 2009. The use of an immunization information system to establish baseline childhood immunization rates and measure contract objectives. J Public Health Manag Pract. 15(5), E6-12. PubMed http://dx.doi.org/10.1097/PHH.0b013e3181a391ba

3. Groom H, et al. 2010. Qualitative Analysis of Immunization Programs With Most Improved Childhood Vaccination Coverage From 2001 to 2004. J Public Health Manag Pract. 16(1), E1-8. doi:http://dx.doi.org/10.1097/PHH.0b013e3181b0b8bc. PubMed

4. Derose SF, et al. 2003. Developing quality indicators for local health departments: experience in Los Angeles County. Am J Prev Med. 25(4), 347-57 PubMed http://dx.doi.org/10.1016/S0749-3797(03)00208-3

5. Rutherford GW, et al. 2010. Public health triangulation: approach and application to synthesizing data to understand national and local HIV epidemics. BMC Public Health. 10(1), 447. PubMed http://dx.doi.org/10.1186/1471-2458-10-447

6. Merrill, J., J. Keeling, and K. Gebbie, Toward Standardized, Comparable Public Health Systems Data: A Taxonomic Description of Essential Public Health Work. Health Services Research, 2009. 44(5p2): p. 1818-1841.

7. Vest JR, Kirk H, Issel L. 2012. Quality and integration of public health information systems: A systematic review focused on immunization and vital records systems. Online J Public Health Inform. 4(2), 1-18. PubMed http://dx.doi.org/10.5210/ojphi.v4i2.4198 
8. Beitsch LM, et al. 2006. Roles of Local Public Health Agencies Within the State Public Health System. J Public Health Manag Pract. 12(3), 232-41. ㅁubMed http://dx.doi.org/10.1097/00124784-200605000-00003

9. Salinsky E, Gursky EA. 2006. The Case For Transforming Governmental Public Health. Health Aff(Millwood). 25(4), 1017-28. PubMed http://dx.doi.org/10.1377/hlthaff.25.4.1017

10. Powell T, Hanfling D, Gostin L. 2012. Emergency preparedness and public health: The lessons of hurricane sandy. JAMA. 308(24), 2569-70.

http://dx.doi.org/10.1001/jama.2012.108940

11. Hasselbring W. 2000. Information system integration. Commun ACM. 43(6), 32-38. http://dx.doi.org/10.1145/336460.336472

12. Baisch MJ, Olsen J, Kreuser NJ. The status of LHD information systems:a critical need for coordination to inform meaningful health improvement initiatives, in PHSSR Keeneland Conference2013: Lexington, KY.

13. Vest JR, Menachemi N, Ford E. 2012. Governance's role in local health departments' information system and technology usage. J Public Health Manag Pract. 18(2), 160-68. PubMed http://dx.doi.org/10.1097/PHH.0b013e318226c9ef

14. Turning Point National Excellence Collaborative for Information Technology, Final Report of the Collaborative, 2005.

15. Centers for Medicare \&amp; Medicaid Services. Stage 2 Meaningful Use Specification Sheet Table of Contents for Eligible Hospitals and CAHs. 2012; Available from:

http://www.cms.gov/Regulations-and-

Guidance/Legislation/EHRIncentivePrograms/Downloads/Stage2_MeaningfulUseSpecSheet _TableContents_EligibleHospitals_CAHs.pdf.

16. Association of State \& Territorial Health Officials, ASTHO Profile of State Public Health. Volume 2, 2011.

17. National Association of County \& City Health Officials. 2010 National Profile of Local Health Departments, 2011: Washington, DC.

18. Mahon BE, et al. 2008. Implications for registry-based vaccine effectiveness studies from an evaluation of an immunization registry: a cross-sectional study. BMC Public Health. 8, 160. PubMed http://dx.doi.org/10.1186/1471-2458-8-160

19. National Association of City and County Health Officials. Adult Hepatitis B Virus (HBV) Vaccination: An Implementation Guide for Local Public Health, in Resources for Infectious Diease Control and Prevention2010, NACCHO.

20. Papadouka V, Metroka A, Zucker JR. 2011. Using an Immunization Information System to Facilitate a Vaccine Recall in New York City, 2007. J Public Health Manag Pract. 17(6), 565-68. PubMed http://dx.doi.org/10.1097/PHH.0b013e3182214746

21. Vest JR, Issel L. Data Sharing between Local Health and State Health Departments: Developing and Describing a Typology of Data Gaps. J Public Health Manag Pract. (In press). PubMed

22. Lee YW, et al. 2002. AIMQ: a methodology for information quality assessment. Inf Manage. 40(2), 133-46. http://dx.doi.org/10.1016/S0378-7206(02)00043-5

23. Pipino LL, Lee YW, Wang RY. 2002. Data quality assessment. Commun ACM. 45(4), 21118. http://dx.doi.org/10.1145/505248.506010

24. Thomas DR. 2006. A General Inductive Approach for Analyzing Qualitative Evaluation Data. Am J Eval. 27(2), 237-46. http://dx.doi.org/10.1177/1098214005283748 
25. Behrens S, Sedera W. Why Do Shadow Systems Exist after an ERP Implementation? Lessons from a Case Study. in PACIS 2004 Proceedings. 2004.

26. Roush S, et al. 1999. Mandatory reporting of diseases and conditions by health care professionals and laboratories. JAMA. 282(2), 164-70. PubMed

http://dx.doi.org/10.1001/jama.282.2.164

27. Bartlett DL, et al. 2007. Cost Savings Associated With Using Immunization Information Systems for Vaccines for Children Administrative Tasks. J Public Health Manag Pract. 13(6), 559-66. PubMed http://dx.doi.org/10.1097/01.PHH.0000296130.39519.f0

28. Quach S, et al. 2011. Time and motion study to compare electronic and hybrid data collection systems during the pandemic (H1N1) 2009 influenza vaccination campaign. Vaccine. 29(10), 1997-2003. PubMed http://dx.doi.org/10.1016/j.vaccine.2010.09.016

29. Brownson RC, Fielding JE, Maylahn CM. 2009. Evidence-Based Public Health: A Fundamental Concept for Public Health Practice. Annu Rev Public Health. 30(1), 175-201. PubMed http://dx.doi.org/10.1146/annurev.publhealth.031308.100134

30. Li J, Shah GH, Hedberg C. 2011. Complaint-based surveillance for foodborne illness in the United States: a survey of local health departments. J Food Prot. 74(3), 432-37. PubMed http://dx.doi.org/10.4315/0362-028X.JFP-10-353

31. Harrison MI, Koppel R, Bar-Lev S. 2007. Unintended Consequences of Information Technologies in Health Care-An Interactive Sociotechnical Analysis. J Am Med Inform Assoc. 14(5), 542-49. PubMed http://dx.doi.org/10.1197/jamia.M2384

32. Bostrom RP, Heinen JS. 1977. MIS Problems and Failures: A Socio-Technical Perspective. Part I: The Causes. Manage Inf Syst Q. 1(3), 17-32. http://dx.doi.org/10.2307/248710

33. Jones $\mathrm{D}$, et al. The rise and fall of a shadow system: lessons for enterprise system implementation. in Australasian Conference on Information Systems (ACIS). 2004.

34. Sherman R. The Data Shadow System Conundrum. Information Management 200609 MAY 2013]; Available from: http://www.informationmanagement.com/issues/20060501/1053406-1.html.

35. Bayan R. Shed light on shadow IT groups. TechRepublic 200409 MAY 2013]; Available from: http://www.techrepublic.com/article/shed-light-on-shadow-it-groups/5247674.

36. Ouellette P. South Carolina HHS data breach update: Indictments dealt. HealthITSecurity 201309 MAY 2013]; Available from: http://healthitsecurity.com/2013/02/20/southcarolina-hhs-data-breach-update-indictments-dealt/.

37. Smith TA, et al. 2007. From Theory to Practice: What Drives the Core Business of Public Health? J Public Health Manag Pract. 13(2), 169-72. http://dx.doi.org/10.1097/00124784-200703000-00013

38. Institute of Medicine. Committee on Public Health Strategies to Improve Health, For the Public's Health. Investing in a Healthier Future. 2012, Washington, DC: National Academies Press.

39. Rasulnia B, Kelly J. 2005. Immunization information system progress--United States, 2003. MMWR Morb Mortal Wkly Rep. 54(29), 722-24. PubMed

40. Public Health Accreditation Board. Standards \& Measures Version 1.0. 201110 April 2012]; Available from: http://www.phaboard.org/wp-content/uploads/PHAB-Standards-andMeasures-Version-1.0.pdf.

41. Lenert L, Sundwall DN. 2012. Public Health Surveillance and Meaningful Use Regulations: A Crisis of Opportunity. Am J Public Health. 102(3), e1-7. $\quad \underline{\text { PubMed }}$ http://dx.doi.org/10.2105/AJPH.2011.300542 
42. Burke T. 2010. The health information technology provisions in the American Recovery and Reinvestment Act of 2009: implications for public health policy and practice. Public Health Rep. 125(1), 141-45. PubMed

\section{Appendix.}

Themes and codes with definitions used identified from content analysis of interviews with local public health practitioners.

\begin{tabular}{|c|c|c|}
\hline Theme & Code & Definition \\
\hline \multirow[t]{5}{*}{$\begin{array}{l}\text { Barriers to } \\
\text { data } \\
\text { acquisition } \\
\text { from others }\end{array}$} & & $\begin{array}{l}\text { The system level context, organizational level factors, } \\
\text { or situations that affect the need or ability of staff to } \\
\text { get information from other organizations or sources }\end{array}$ \\
\hline & $\begin{array}{l}\text { Jurisdictionally } \\
\text { defined work }\end{array}$ & $\begin{array}{l}\text { Differing roles and IS responsibilities based on political } \\
\text { areas/jurisdictions or geographic areas of program } \\
\text { implementation/oversight, as it pertains to subsequent } \\
\text { acquisition of data }\end{array}$ \\
\hline & $\begin{array}{l}\text { Mobile } \\
\text { populations }\end{array}$ & $\begin{array}{l}\text { Citizens/patients receive services at various locations } \\
\text { which fall under different jurisdictions with different IS/ } \\
\text { forms/ policies, as explanation of why data acquisition is } \\
\text { difficult }\end{array}$ \\
\hline & Data ownership & $\begin{array}{l}\text { Description of which organization(s) or departments } \\
\text { control/owns which data elements or overall data that are } \\
\text { needed, as it pertains to subsequent acquisition of data }\end{array}$ \\
\hline & $\begin{array}{l}\text { Data access } \\
\text { control }\end{array}$ & $\begin{array}{l}\text { Nontechnical aspects and policies of departments that } \\
\text { determine who can access /use what information in } \\
\text { existing IS; blocked access to needed data elements }\end{array}$ \\
\hline \multirow{6}{*}{$\begin{array}{l}\text { Barriers to } \\
\text { effective data } \\
\text { sharing (to } \\
\text { others) }\end{array}$} & & $\begin{array}{l}\text { Experienced and reported difficulties, challenges or } \\
\text { factors/situations that need to be overcome/addressed } \\
\text { in order to provide data to others }\end{array}$ \\
\hline & $\begin{array}{l}\text { Multiple data } \\
\text { partners at state }\end{array}$ & $\begin{array}{l}\text { Having to deal with different state offices / agencies / } \\
\text { departments for data related to a given health topic }\end{array}$ \\
\hline & $\begin{array}{l}\text { More than } 1 \text { IS } \\
\text { to do job }\end{array}$ & $\begin{array}{l}\text { Job or single task requires the access / use of more than } 1 \\
\text { information system }\end{array}$ \\
\hline & $\begin{array}{l}\text { Task technology } \\
\text { fit }\end{array}$ & $\begin{array}{l}\text { Issues regarding the match or appropriateness of the } \\
\text { design of the IS to public health work, including } \\
\text { fragmentation of the IS across agencies/departments }\end{array}$ \\
\hline & $\begin{array}{l}\text { Organizational } \\
\text { capabilities }\end{array}$ & $\begin{array}{l}\text { Skills within the organization /department (analytic, } \\
\text { technical) to be able to use information, as antecedent to } \\
\text { sharing data or reports }\end{array}$ \\
\hline & Reporting back & $\begin{array}{l}\text { Lack of information flow back from other organizations } \\
\text { and departments with whom data had been shared (ie, } \\
\text { reports) regarding use or quality of those data; no }\end{array}$ \\
\hline
\end{tabular}




\begin{tabular}{|c|c|c|}
\hline & & feedback loop \\
\hline \multirow{6}{*}{$\begin{array}{l}\text { Organizational } \\
\text { sharing } \\
\text { partner }\end{array}$} & & $\begin{array}{l}\text { Attribute code to clarify / describe who data sharing } \\
\text { is occurring with. }\end{array}$ \\
\hline & Other LHD & Other local health departments in other jurisdictions. \\
\hline & $\begin{array}{l}\text { State health } \\
\text { agency - general }\end{array}$ & $\begin{array}{l}\text { The state health agency in general - not specific to any } \\
\text { unit or department with the agency }\end{array}$ \\
\hline & $\begin{array}{l}\text { State counterpart } \\
\text { department }\end{array}$ & $\begin{array}{l}\text { The counterpart department with the state health agency } \\
\text { (e.g. immunizations, communicable disease, vital } \\
\text { records) }\end{array}$ \\
\hline & Providers & Any healthcare organization, provider or physicians \\
\hline & Other & $\begin{array}{l}\text { All other organizations (funeral homes, charities, social } \\
\text { services, etc) }\end{array}$ \\
\hline \multirow[t]{13}{*}{$\begin{array}{l}\text { Factors } \\
\text { affecting ISQ }\end{array}$} & & $\begin{array}{l}\text { Descriptions of factors, circumstances, or conditions } \\
\text { that affect specific quality characteristics or overall } \\
\text { quality of the data within the IS }\end{array}$ \\
\hline & Sources of Error & $\begin{array}{l}\text { Explanations of how errors are introduced into the data, } \\
\text { general comments regarding sources or extent of errors }\end{array}$ \\
\hline & $\begin{array}{l}\text { Data } \\
\text { logistics/Work } \\
\text { processes }\end{array}$ & $\begin{array}{l}\text { Descriptions of the work process of collecting \& } \\
\text { reporting information and the ways those work processes } \\
\text { are related to specific or overall data quality }\end{array}$ \\
\hline & Use paper for job & $\begin{array}{l}\text { Instances where paper is required or used in parallel with } \\
\text { IS (both forms \& as a paper-based record keeping) in } \\
\text { order to have complete data (not shadow system) }\end{array}$ \\
\hline & ISQ timeliness & $\begin{array}{l}\text { Issues affecting or perceptions of the timeliness of the } \\
\text { data in the IS }\end{array}$ \\
\hline & ISQ missing Info & $\begin{array}{l}\text { The type or extent of information that is missing in the } \\
\text { IS, either specific data elements or entire records }\end{array}$ \\
\hline & ISQ accuracy & $\begin{array}{l}\text { The type or extent of information inaccuracies, such as } \\
\text { wrong values or unbelievable information }\end{array}$ \\
\hline & ISQ accessibility & $\begin{array}{l}\text { Technical and software factors related to the availability } \\
\text { and retrieval of information from the IS; user friendliness } \\
\text { of the IS interface }\end{array}$ \\
\hline & $\begin{array}{l}\text { Security and } \\
\text { confidentiality }\end{array}$ & $\begin{array}{l}\text { Issues related to assuring the security and confidentiality } \\
\text { of the data as they effect data quality (ie, ability to edit } \\
\text { and correct data), irrespective of data ownership }\end{array}$ \\
\hline & $\begin{array}{l}\text { ISQ multiple } \\
\text { data sources }\end{array}$ & $\begin{array}{l}\text { Factors related to the quality of the information due to } \\
\text { multiple users (ie data managers, data entry personnel, } \\
\text { providers) or multiple sources of the information }\end{array}$ \\
\hline & $\begin{array}{l}\text { ISQ } \\
\text { interoperability }\end{array}$ & $\begin{array}{l}\text { Factors related to the ability of the IS to export/import } \\
\text { data from other information and computer systems }\end{array}$ \\
\hline & $\begin{array}{l}\text { ISQ reporting / } \\
\text { output capability }\end{array}$ & $\begin{array}{l}\text { Ability to manipulate the data or generate output/reports } \\
\text { using the existing software }\end{array}$ \\
\hline & $\begin{array}{l}\text { ISQ inclusion } \\
\text { rules }\end{array}$ & $\begin{array}{l}\text { What makes individuals eligible to have their data } \\
\text { included in the IS }\end{array}$ \\
\hline
\end{tabular}




\begin{tabular}{|c|c|c|}
\hline \multirow[t]{6}{*}{$\begin{array}{l}\text { Consequences } \\
\text { of Data } \\
\text { Sharing } \\
\text { Barriers and } \\
\text { ISQ Problems }\end{array}$} & & $\begin{array}{l}\text { All consequences or outcomes associated with the } \\
\text { inability to efficiently secure desired information } \\
\text { from other sources and of having poor data quality }\end{array}$ \\
\hline & $\begin{array}{l}\text { Duplication of } \\
\text { work/re-work / } \\
\text { inefficient work }\end{array}$ & $\begin{array}{l}\text { Repeat of work or use of inefficient work practices (ie } \\
\text { calling to get missing data) stemming from having poor } \\
\text { IS quality or data logistic procedures }\end{array}$ \\
\hline & Workarounds & $\begin{array}{l}\text { Additional work processes and communication efforts } \\
\text { developed and used to overcome /get around /avoid } \\
\text { barriers encountered in data availability or use }\end{array}$ \\
\hline & Shadow IS & $\begin{array}{l}\text { Creation and use of additional IS or duplicate IS, } \\
\text { databases, or repositories, due to accessibility or } \\
\text { functionality issues, in order to store and use information } \\
\text { already available in other system, such that staff do not } \\
\text { work from a single IS }\end{array}$ \\
\hline & $\begin{array}{l}\text { Effects decision } \\
\text { making }\end{array}$ & $\begin{array}{l}\text { Limits strategic planning, community } \text { planning, } \\
\text { environmental scanning, or } \\
\text { resulting from incomplete data }\end{array}$ \\
\hline & $\begin{array}{l}\text { Effects health } \\
\text { problems }\end{array}$ & $\begin{array}{l}\text { Negative effects for health of individuals or populations } \\
\text { resulting from IS problems }\end{array}$ \\
\hline \multirow[t]{3}{*}{$\begin{array}{l}\text { Hardware } \\
\text { Considerations }\end{array}$} & & $\begin{array}{l}\text { Descriptions of concerns, issues, or experiences } \\
\text { specifically related to computer hardware and its } \\
\text { maintenance }\end{array}$ \\
\hline & $\begin{array}{l}\text { Hardware \& data } \\
\text { backups }\end{array}$ & $\begin{array}{l}\text { Comments regarding the characteristics of the hardware } \\
\text { which affects its usefulness (ie interface of parts), and of } \\
\text { the degree of capability to maintain backups }\end{array}$ \\
\hline & System stability & $\begin{array}{l}\text { Comments regarding the reliability of the hardware in } \\
\text { terms of having an overall stable computer system (ie, } \\
\text { not crash) }\end{array}$ \\
\hline \multirow[t]{3}{*}{$\begin{array}{l}\text { Data Quality } \\
\text { focused } \\
\text { Solutions } \\
\end{array}$} & & $\begin{array}{l}\text { Descriptions of anticipated or actual ways identified } \\
\text { to correct or overcome the known problems with the } \\
\text { actual data elements }\end{array}$ \\
\hline & $\begin{array}{l}\text { Identify \& } \\
\text { correct error }\end{array}$ & $\begin{array}{l}\text { Actions to pin-point the incorrect data element or record, } \\
\text { and the associated actions to correct that specific error in } \\
\text { the data }\end{array}$ \\
\hline & $\begin{array}{l}\text { Technical } \\
\text { support }\end{array}$ & $\begin{array}{l}\text { Support options available to help with issues / correct } \\
\text { mistakes or provide analytics }\end{array}$ \\
\hline \multirow[t]{2}{*}{$\begin{array}{l}\text { Sharing } \\
\text { focused } \\
\text { Solutions }\end{array}$} & & $\begin{array}{l}\text { Descriptions of anticipated, potential or actual ways } \\
\text { identified to correct or overcome the known } \\
\text { information sharing problems }\end{array}$ \\
\hline & Regionalization & $\begin{array}{l}\text { Changing of jurisdictional limitations to focus on larger } \\
\text { community areas as means to improve data sharing }\end{array}$ \\
\hline Benefits of IS & & $\begin{array}{l}\text { Descriptions of perceived or actual advantages to } \\
\text { individuals and populations, and organizations from }\end{array}$ \\
\hline
\end{tabular}




\begin{tabular}{|c|c|c|}
\hline & & having an IS \\
\hline & $\begin{array}{l}\text { Customer } \\
\text { benefits }\end{array}$ & $\begin{array}{l}\text { Benefits seen by customers, citizens, society from having } \\
\text { accurate, timely data }\end{array}$ \\
\hline \multirow[t]{8}{*}{$\begin{array}{l}\text { Use of } \\
\text { information }\end{array}$} & & $\begin{array}{l}\text { Descriptions and explanations of how public health } \\
\text { practitioners apply (or fail to) information }\end{array}$ \\
\hline & $\begin{array}{l}\text { Useful } \\
\text { information }\end{array}$ & Comments on the overall usefulness/not of the data in IS \\
\hline & Management & $\begin{array}{l}\text { Executive, administrative or managerial uses of } \\
\text { information to help the work and operation of the LHD }\end{array}$ \\
\hline & $\begin{array}{l}\text { Community } \\
\text { partners }\end{array}$ & Sharing of information and reports with the community \\
\hline & Practitioners & $\begin{array}{l}\text { How individual practitioners apply information to public } \\
\text { health activities }\end{array}$ \\
\hline & $\begin{array}{l}\text { Other } \\
\text { government } \\
\text { partners }\end{array}$ & Sharing of information with other government partners \\
\hline & $\begin{array}{l}\text { Required state } \\
\text { reports }\end{array}$ & Use of information in required reports to the state \\
\hline & Required sharing & $\begin{array}{l}\text { Instances of mandatory or obligatory reporting to other } \\
\text { agencies }\end{array}$ \\
\hline \multirow[t]{4}{*}{ IS Uers' Views } & & $\begin{array}{l}\text { Descriptions of personal views, opinions and } \\
\text { perspectives on the current and future of the IS that } \\
\text { individual is working with }\end{array}$ \\
\hline & $\begin{array}{l}\text { Personal } \\
\text { responses to IS }\end{array}$ & $\begin{array}{l}\text { Emotions (positive and negative) triggered by working } \\
\text { with the IS }\end{array}$ \\
\hline & $\begin{array}{l}\text { Meaning of } \\
\text { information \& } \\
\text { data }\end{array}$ & $\begin{array}{l}\text { Distinctions made or differences mentioned between data } \\
\text { and information }\end{array}$ \\
\hline & Full vision & $\begin{array}{l}\text { Re-thinking about how IT/IS should support public } \\
\text { health and what changes should occur to new systems }\end{array}$ \\
\hline
\end{tabular}

